\title{
Agricultural and Aquacultural Potential of Olive Pomace
}

\section{A Review}

\author{
Constantina Nasopoulou ${ }^{1} \&$ Ioannis Zabetakis ${ }^{1}$ \\ ${ }^{1}$ Laboratory of Food Chemistry, Faculty of Chemistry, National and Kapodistrian University of Athens, Athens \\ 15771, Greece
}

Correspondence: Ioannis Zabetakis, Laboratory of Food Chemistry, Faculty of Chemistry, National and Kapodistrian University of Athens, Athens 15771, Greece. Tel: 30-210-7274-663. E-mail: izabet@chem.uoa.gr

$\begin{array}{lr}\text { Received: April 25, } 2013 & \text { Accepted: May 28, } 2013 \quad \text { Online Published: June 15, } 2013 \\ \text { doi:10.5539/jas.v5n7p116 } & \text { URL: http://dx.doi.org/10.5539/jas.v5n7p116 }\end{array}$

\begin{abstract}
Olive Pomace (OP) is the main agricultural by-product of olive industry; because of its nature, it is a major environmental issue for all the olive-producing countries. Research on the waste-management issues of OP has been active over the last decade. The data presented in the present review suggest that OP could be exploited as an alternative dietary lipid source in compounded fish feeds resulting in the formulation of functional fish feeds and aquacultured fish according to the EU legislation (EC 1924/2006). Moreover OP can also be used in agriculture by inclusion in animal feeds without attenuating animal performance and meat quality.

In this review, all the latest results on the in vitro and in vivo studies regarding the usage of OP in fish and animal feeds are evaluated and the environmental and nutritional implications for aquaculture and agriculture industries are presented.
\end{abstract}

Keywords: sustainability, olive pomace, fish feeds, animal feeds, atherosclerosis.

\section{Introduction}

The steadily increase of global population - it is likely to plateau at 9 billion people by roughly the middle of this century - results in higher food consumption and increased demand for processed food, meat, dairy and fish (Charles et al., 2010). At the same time the biggest challenge for food industries and scientists is to develop environmentally sustainable procedures of food production reinsuring food security and suppressing environmental pollution.

For this reason food chain management practices have to be altered using a more holistic approach, i.e. could the by-products of one production area be used as raw ingredients in another one? To answer this question, a fresh approach is required that combines thoughtful resource management with the ultimate aim that the final product can satisfy the human population's needs in terms of quantity but also meet the customers' wishes for advanced sensory properties (i.e. odour, taste and aftertaste) and nutritional value.

In terms of food security in aquaculture, it is necessary to overcome the obstacle of fish oil dependence on the sustainable production of fish feed. Currently, one million tonnes of fish oil are produced on an annual basis (Pike \& Jackson, 2010), while $40 \%$ and $60 \%$ of the global production of fish meal and fish oil, respectively, are used in aquaculture (Nasopoulou \& Zabetakis, 2012). Salmonid diets alone consumed over 55\% of the fish oil used by the aquaculture sector in 2006 (Jackson, 2007). About 50\% of world marine fish stocks have recently been estimated as fully exploited, $32 \%$ as overexploited and only $15 \%$ as under-exploited (FAO, 2010). These exploitation data suggest that the diminishing levels of available wild fish worldwide combined with the fact that aquacultured carnivorous species require large amounts of wild fish in their feed (Naylor et al., 2000) create an emerging necessity to improve our resource management practices. New, alternative, lipid sources need to be identified and valorised in order to achieve sustainable production of fish feeds, enabling further development of aquaculture applications. Such a promising lipid source could be olive pomace (OP).

OP has also been proposed as an alternative source of nutrients for domestic animal feeding (Sansoucy, 1985), while the advantages of using agricultural by-products such as OP in livestock feeding are not only on minimizing environmental pollution, but also reducing dependency on highly expensive ingredients such as grains and roughages (Grasser, Fadel, Garnett, \& Depeters, 1995). 


\section{OP's Sources and Nutritional Value}

OP is one of two major by-products of the olive oil extraction industry when using the three-phase centrifugal technology, the other being the olive mill waste water (OMWW) (Brunetti, Plaza, \& Senesi, 2005; Cardoso, Silva, \& Coimbra, 2002). Thus OP is a natural agricultural by-product of olive oil production. The modern two-phase centrifugal extraction technology - a more efficient and environmentally friendly centrifugation process - merges OP with OMWW to produce a single by-product named olive mill waste (OMW), containing higher moisture and lower oil content compared to the traditional three-phase centrifugal technology by-product (Alburquerque, Gonzalvez, Garcia, \& Cegarra, 2004).

The annual production of olive oil is estimated to be 2.9 million tonnes with some 15 million tonnes of OMW being produced annually (Roig, Cayuela, \& Sánchez-Monedero, 2006). In Mediterranean countries, the production of olives has been a major part of the agricultural produce of these countries for many decades (if not centuries). For every $100 \mathrm{~kg}$ of olives, $35 \mathrm{~kg}$ of OP are produced; it could, thus, be suggested that the production of OMW and OP are sustainable and the availability of OP for use in any type of feed production and thus aquaculture should not be a problem.

The price of OP is $€ 0.1-0.2 / \mathrm{kg}$, rendering it as price competitive compared to other vegetable oils. This cost linked to the fact that $4-8 \%$ of OP is needed to be included in the fish feed formulation make OP as a promising lipid source for aquaculture. The problem of transferring OP from Mediterranean countries to Northern Europe or to other places of the world could be rationalised by extracting the polar lipids of OP that they are the active feed components and therefore reducing the volume of material that needs to be transported.

The chemical composition of OMWW and the percentage of fatty acids are given in Tables $1 \mathrm{a}$ and $1 \mathrm{~b}$, respectively. OP's oil and water content depends on the process applied and on the operating conditions; it contains about $8 \%$ oil and the recovery of oil is carried out by extraction with solvent. In order to make the oil edible, OP has to be deacidified, bleached and deodorized (Di Giovacchino, 1996). After refining, refined OP oil is mixed with virgin olive oil and is thus eligible for the commercial class of OP oil as defined by European Community (EC) Regulation No. 356/92 (Official Journal of EC, 1992). This process is needed only in the case of rendering OP as edible for human consuption and it is not required in animal and fish feed applications, such the ones proposed in this review paper.

OP retains a small amount of olive oil and consists mainly of water, olive skin, olive flesh, fragments of pulp and pieces of kernels. OP chemical composition is generally characterized by a high content of crude fiber and sugars (mainly polysaccharides) and moderate values of crude protein, fatty acids (oleic acid 18:1 $\omega-9$ ), polyalcohols, polyphenols and other pigments (Borja, Martín, Rincón, \& Raposo, 2003; Brunetti et al., 2005; Muik, Lendl, Molina-Díaz, Pérez-Villarejo, \& Ayora-Cañada, 2004; Saviozzi, Levi-Minzi, Cardelli, Biasci, \& Riffaldi, 2001). A variety of substances with proven antioxidant and radical scavenging activity, such as hydroxytyrosol (3, 4 DHPEA), tyrosol (p-HPEA) and their secoiridoid derivatives (dialdheydic form of decarboxymethyl elenolic acid, 3, 4 -DHPEA-EDA or p-HPEA-EDA) as well as verbascoside, is also contained in OP (Amro, Aburjai, \& Al-Khalil, 2002)

However, the chemical composition of OPs may vary widely in relation to the agronomic and technological conditions of production. Additionally, the olive cultivar is one of the most important factors that affect the phenolic content of olive oil and by-products (Martín García, Moumen, Yáñez Ruiz, \& Molina-Alcaide, 2004; Servili et al., 2011).

The ability of OP's long-chain fatty alcohols to inhibit the release of different pro-inflammatory mediators has been studied in vitro, using cells involved in inflammatory processes (Fernández-Arche et al., 2009). More specifically, OP's alcohols inhibited the induced nitric oxide synthetase expression and thus the levels of nitric oxide but also they reduced tumor necrosis factor- $\alpha(\mathrm{TNF}-\alpha)$ and the production of prostaglandin $\mathrm{E}_{2}$.

The effect of diets supplemented with fish oil (FO), refined olive oil (ROO) and pomace olive oil (POO) was studied using weaned male Swiss albino mice and it was found that ROO and POO significantly reduced the production of hydrogen peroxide and the generation of nitric oxide (De la Puerta, Marquez-Martin, Fernandez-Arche et al., 2009). It could thus be suggested that OP helps the prevention of cellular oxidative stress and inflammation. In another study, the effects of long-term intake of diets enriched in POO on endothelial dysfunction associated to hypertension in small mesenteric arteries have been evaluated (Rodriguez-Rodriguez, Herrera, Alvarez de Sotomayor, \& Ruiz-Gutierrez, 2009). The authors have suggested that consumption of POO improves the endothelial function in these arteries. The effect of OP's polyphenol extracts, on endothelial cells subjected to anoxia, has also recently been studied (Palmieri et al., 2012); it was concluded that this extract has the 
ability to restore the endothelial functions that are impaired by anoxia by regulating the genes expression that are involved in proteolysis, angiogenesis and inflammation.

Table 1 . The chemical composition and the fatty acid profile of olive mill waste water (OMWW) and olive pomace (OP) (Bosco et al., 2012; Sicuro et al., 2010)

\begin{tabular}{|c|c|c|c|c|}
\hline Compound & $\mathrm{OMWW}^{\mathrm{a}}\left(\mathrm{g} \mathrm{L}^{-1}\right)$ & $\mathrm{OP}^{1, b}\left(\mathrm{~g} \mathrm{~kg}^{-1}\right)$ & $\mathrm{OP}^{2, \mathrm{~b}}$ & $\mathrm{OP}^{3, \mathrm{~b}}$ \\
\hline Sugars & 3.4 & & & \\
\hline Protein & 3.2 & & & \\
\hline Lipids & 5.6 & & & \\
\hline Polyphenols & 4.99 & & & \\
\hline 3,4-DHPEA & & $1.3 \pm 0.01$ & $1.5 \pm 0.01$ & $1.1 \pm 0.01$ \\
\hline$p$-HPEA & & $0.7 \pm 0.01$ & $1.0 \pm 0.01$ & $1.4 \pm 0.01$ \\
\hline 3,4-DHPEA-EDA & & $8.3 \pm 0.6$ & $17.0 \pm 1.7$ & $22.0 \pm 1.2$ \\
\hline$p$-HPEA-EDA & & $1.1 \pm 0.01$ & $6.9 \pm 0.7$ & $10.1 \pm 0.1$ \\
\hline Ortho-diphenols & 0.46 & $4.1 \pm 0.4$ & $8.0 \pm 0.1$ & $9.9 \pm 1.0$ \\
\hline Total suspended solids & 44.26 & & & \\
\hline Natural organic material & 142.2 & & & \\
\hline $\mathrm{pH}$ & 4.32 & & & \\
\hline Fatty acid composition & $\begin{array}{l}\mathrm{OMWW}^{\mathrm{a}} \\
\text { (\% of total) }\end{array}$ & $\mathrm{OP}^{1, \mathrm{~b}}$ & $\mathrm{OP}^{2,6}$ & $\mathrm{OP}^{3, \mathrm{~b}}$ \\
\hline 14:0 & 0.03 & & & \\
\hline 16:0 & 16.90 & $13.8 \pm 0.3$ & $13.0 \pm 0.2$ & $11.8 \pm 0.3$ \\
\hline 16:1 & 1.60 & & & \\
\hline 17:0 & 0.18 & & & \\
\hline $17: 1$ & 0.06 & & & \\
\hline 18:0 & 0.40 & $2.2 \pm 0.1$ & $2.6 \pm 0.1$ & $2.6 \pm 0.1$ \\
\hline 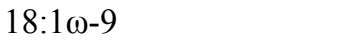 & 73.10 & $69.4 \pm 1.8$ & $74.0 \pm 1.6$ & $76.3 \pm 1.8$ \\
\hline $18: 2 \omega-6$ & 7.70 & $9.5 \pm 0.3$ & $7.6 \pm 0.2$ & $7.7 \pm 0.4$ \\
\hline $18: 3 \omega-6$ & 0.16 & $1.0 \pm 0.1$ & $1.1 \pm 0.2$ & $0.9 \pm 0.1$ \\
\hline$\omega-6$ & 7.86 & & & \\
\hline Saturated & 17.51 & $16.1 \pm 0.2$ & $15.6 \pm 0.4$ & $14.4 \pm 0.2$ \\
\hline MUFA & 74.76 & $69.4 \pm 1.7$ & $74 \pm 1.6$ & $76.3 \pm 1.7$ \\
\hline PUFA & 7.86 & $10.5 \pm 0.4$ & $8.7 \pm 0.2$ & $8.7 \pm 0.4$ \\
\hline$\omega-3 / \omega-6$ & & $0.1 \pm 0.1$ & $0.2 \pm 0.1$ & $0.1 \pm 0.1$ \\
\hline
\end{tabular}

$\mathrm{OP}^{1}$ : mixed olive cultivars; $\mathrm{OP}^{2}:$ Frantoio olive cultivar; $\mathrm{OP}^{3}$ : Coratina olive cultivar; 3,4-DHPEA: hydroxytyrosol; p-HPEA: tyrosol; 3,4-DHPEA-EDA: 3,4-DHPEA secoiridoid derivative and p-HPEA-EDA: p-HPEA secoiridoid derivative.

a: Sicuro et al., 2010.

${ }^{\mathrm{b}}$ : Bosco et al., 2012.

Apart from these studies on extracts of OP, the nutritional value of OP has been evaluated in terms of atheroprotective activity against Platelet Activating Factor (PAF) (namely PAF-inhibitors) (Karantonis et al., 2008). PAF is a phospholipid mediator implicated in atherogenesis (Demopoulos, Karantonis, \& Antonopoulou, 2003). When PAF levels are increased in blood, that occur both in pathological inflammatory conditions and during oxidative stress through low density lipoprotein (LDL) and membrane phospholipid oxidation, the initiation of atherosclerosis occurs. Food constituents that can act as PAF-inhibitors or antagonists have the potential to retard the onset of atherosclerosis and the subsequent development of cardiovascular diseases (CVDs). Thus, the presence of PAF- inhibitors or PAF-antagonists in OP is very important in terms of cardio-protection. It 
was found in vitro that OP contains polar lipids compounds that inhibit or antagonize PAF and thus OP could be valorized in the production of food with higher nutritional value (Karantonis et al., 2008).

Further studies on OP have shown that the polar lipids of OP possess in vivo antiatherogenic properties since they contain PAF specific antagonists with similar bioactivity to those of olive oil. These bioactive microconstituents inhibit both specific PAF binding and PAF activity (in vitro and in vivo), consequently inhibiting early atherosclerosis development (Tsantila et al., 2007). The beneficial effect of OP polar lipids extract on the atherogenic progress (dyslipidemia and lesions) has also been studied (Tsantila et al., 2010); it was demonstrated that the polar lipids of OP exert cardioprotective effects comparable to those of simvastatin. This result coupled with the cost-effectiveness of OP polar lipids extraction warrants further investigation of the anti-atherogenic potential of this OP extract and its potential as a fish feed ingredient in aquaculture. All the above mentioned studies are summarised in Table 2.

Table 2. Nutritional value of olive pomace in terms of cardio-protection

\begin{tabular}{|c|c|c|c|}
\hline $\begin{array}{l}\text { Lipid fraction under } \\
\text { study }\end{array}$ & $\begin{array}{l}\text { Biological function } \\
\text { under study }\end{array}$ & Results & Reference \\
\hline $\begin{array}{l}\text { Long-chain fatty } \\
\text { alcohols }\end{array}$ & Inflammation & $\begin{array}{l}\text { In vitro inhibition of the } \\
\text { release }\end{array}$ & $\begin{array}{l}\text { Fernández-Arche et al., } \\
2009\end{array}$ \\
\hline $\begin{array}{l}\text { (tetracosanol, } \\
\text { hexacosanol and } \\
\text { octacosanol) }\end{array}$ & & $\begin{array}{l}\text { of pro-inflammatory } \\
\text { mediators }\end{array}$ & \\
\hline $\begin{array}{l}\text { Refined olive oil and } \\
\text { olive }\end{array}$ & Inflammation & $\begin{array}{l}\text { In vivo reduction of oxidative } \\
\text { stress }\end{array}$ & De la Puerta et al., 2009 \\
\hline pomace oil & & $\begin{array}{l}\text { and pro-inflammatory } \\
\text { mediators }\end{array}$ & \\
\hline Olive pomace oil & $\begin{array}{l}\text { Endothelial dysfunction } \\
\text { associated } \\
\text { to hypertension }\end{array}$ & $\begin{array}{l}\text { Improvement of endothelial } \\
\text { function }\end{array}$ & $\begin{array}{l}\text { Rodriguez-Rodriguez et } \\
\text { al., } 2009\end{array}$ \\
\hline $\begin{array}{l}\text { Polyphenol extract of } \\
\text { olive } \\
\text { pomace }\end{array}$ & $\begin{array}{l}\text { Anoxia-induced } \\
\text { endothelial dysfunction }\end{array}$ & $\begin{array}{l}\text { Restoration of endothelial } \\
\text { functions }\end{array}$ & Palmieri et al., 2012 \\
\hline Olive pomace & Platelet aggregation & $\begin{array}{l}\text { In vitro reduction of platelet } \\
\text { aggregation }\end{array}$ & Karantonis et al., 2008 \\
\hline $\begin{array}{l}\text { Polar extracts of olive } \\
\text { pomace }\end{array}$ & $\begin{array}{l}\text { Platelet aggregation and } \\
\text { onset of atherosclerosis }\end{array}$ & $\begin{array}{l}\text { In vivo reduction of platelet } \\
\text { aggregation } \\
\text { and formation of atheromatic } \\
\text { lesions }\end{array}$ & Tsantila et al., 2007 \\
\hline $\begin{array}{l}\text { Polar extracts of olive } \\
\text { pomace }\end{array}$ & $\begin{array}{l}\text { Atherosclerosis } \\
\text { regression }\end{array}$ & $\begin{array}{l}\text { In vivo regression of the } \\
\text { atherogenic } \\
\text { progress (dyslipidemia and } \\
\text { lesions) }\end{array}$ & Tsantila et al., 2010 \\
\hline
\end{tabular}

\section{Aquacultural Potential}

One of the basic dietary ingredients in compounded fish feeds for carnivorous marine fish is fish oil due to its high digestibility and sufficient content of essential fatty acids, in particular $\omega-3$ PUFA. Fish oil substitution in fish feeds has come to the forefront only recently, especially when fish feeds production used approximately $75 \%$ of the world fish oil production in 2010. In the next ten years, fish oil production may not cover the total necessary quantity for aquaculture. In order to reduce dependence on fish oil, significant breakthroughs have occurred over the past few years in replacing it with plant oils and all these papers have been recently critically evaluated (Nasopoulou \& Zabetakis, 2012). Regarding the use of OP in fish feeds, the relevant reports are presented here.

The effects of dietary OP oil and L-carnitine on growth and chemical composition of African catfish (Clarias gariepinus) have been reported (Yilmaz, Naz, \& Akyurt, 2004), where two different energy diets (a high one with $9 \%$ OP oil and a low one with $3 \%$ OP oil) were tested in conjunction with the supplementation or not of L-carnitine. 
The fish fed the low energy diet and supplemental L-carnitine had better feed intake and growth. L-carnitine was found to increase total lipids in the muscle and decrease total lipids in the liver. The feeding experiment was carried out for 49 days. The most efficient diets were found to be the ones with $3 \%$ OP oil and these are summarized in Tables 3 and 4.

Olive mill waste water (OMWW at two different ratios (1\% and 5\%) was supplemented in the diet of rainbow trout (Onchorynchus mykyss) for 94 days. At the end of the trial, fish were analysed for their fatty acid content (Table 4). An electronic nose was also used in order to assess the flesh quality. It was found that OMWW diets could enrich the "freshness" odour of the fish flesh. No negative effects were observed on fish growth and feed digestibility and it was thus concluded that OMWW can be used in the manufacture of trout feed (Sicuro et al., 2010).

Table 3. Effect of dietary treatment on growth performance of different fish species

\begin{tabular}{llcccl}
\hline Fish & Dietary Treatment & SGR & FCR & PER & Reference \\
\hline Catfish & Control & 2.93 & 2.71 & 1.23 & Yilmaz et al., 2004 \\
& 3\% OP oil and 2000ppm & 2.91 & 2.47 & 1.40 & \\
& $\begin{array}{l}\text { L-carnitine } \\
\text { 3\% OP oil without L- }\end{array}$ & 2.94 & 2.46 & 1.39 & \\
& carnitine & & & & \\
Rainbow trout & Control & 1.10 & 1.40 & 1.95 & Sicuro et al., 2010 \\
& 1\% OMWW & 1.06 & 1.40 & 1.81 & \\
\multirow{3}{*}{$\begin{array}{l}\text { Gilthead Sea } \\
\text { bream }\end{array}$} & Control & 1.08 & 1.40 & 1.84 & \\
& 8\% OP & 0.35 & 2.03 & n.a. & Nasopoulou, Stamatakis, Demopoulos, \\
& & 0.52 & 1.82 & n.a. & \& Zabetakis, 2011 \\
\hline
\end{tabular}

n.a. data not available

SGR: specific growth rate $=($ final weight - initial weight $) /$ feeding days.

FCR : feed conversion rate $=$ total feed supplied ( $g$ of dry mass) $/$ weight gain $(\mathrm{g})$.

PER : protein efficiency ratio $=$ weight gain $(\mathrm{g}) /$ total protein fed $(\mathrm{g})$.

Table 4. Fatty acid composition of fish obtained for experimental diets presented in Table $3^{*}$

\begin{tabular}{|c|c|c|c|c|c|c|c|c|}
\hline \multirow[b]{2}{*}{ Fatty acid } & \multicolumn{3}{|c|}{ Catfish $^{\mathrm{a}}$} & \multicolumn{3}{|c|}{ Rainbow trout ${ }^{\mathrm{b}}$} & \multicolumn{2}{|c|}{$\begin{array}{c}\text { Gilthead sea } \\
\text { bream }^{c}\end{array}$} \\
\hline & Control & $\begin{array}{l}3 \% \text { OP oil and } 2000 \mathrm{ppm} \\
\text { carnitine }\end{array}$ & $\begin{array}{l}3 \% \text { OP oil, no } \\
\text { carnitine }\end{array}$ & Control & $\begin{array}{l}\% \\
\text { OMWW }\end{array}$ & $\begin{array}{l}5 \% \\
\text { OMWW }\end{array}$ & Control & $8 \%$ OP \\
\hline 14:0 & 1.55 & 1.24 & 1.02 & 3.94 & 3.88 & 4.14 & 4.87 & 8.92 \\
\hline $16: 0$ & 34.14 & 27.87 & 29.17 & 22.7 & 23.8 & 23.9 & $31.87^{\dagger}$ & $30.51^{\dagger}$ \\
\hline $16: 1$ & 2.74 & 1.88 & 2.08 & 5.52 & 5.46 & 5.81 & 7.28 & 11.62 \\
\hline $18: 1 \omega-9$ & 23.15 & 29.58 & 33.44 & 30.2 & 30.0 & 29.9 & $27.44^{\dagger}$ & $36.13^{\dagger}$ \\
\hline $18: 2 \omega-6$ & 14.77 & 18.63 & 14.47 & 9.52 & 9.43 & 9.68 & $14.15^{\dagger}$ & $10.80^{\dagger}$ \\
\hline $20: 5 \omega-3$ & 0.65 & 0.51 & 0.43 & 3.66 & 3.55 & 3.61 & $3.39^{\dagger}$ & $0.71^{\dagger}$ \\
\hline $22: 6 \omega-3$ & 3.03 & 2.68 & 2.94 & 18.21 & 18.21 & 17.78 & $5.65^{\dagger}$ & $0.47^{\dagger}$ \\
\hline Saturated & 49.88 & 41.32 & 41.39 & 30.40 & 30.98 & 31.35 & $42.07^{\dagger}$ & $40.26^{\dagger}$ \\
\hline MUFA & 27.24 & 32.62 & 36.88 & 36.26 & 36.07 & 36.21 & $34.73^{\dagger}$ & $47.78^{\dagger}$ \\
\hline PUFA & 22.98 & 26.55 & 21.89 & 33.41 & 32.83 & 32.53 & $23.20^{\dagger}$ & $11.98^{\dagger}$ \\
\hline$\omega-3 / \omega-6$ & 0.38 & 0.27 & 0.35 & 2.04 & 2.12 & 2.05 & $0.64^{\dagger}$ & $0.11^{\dagger}$ \\
\hline
\end{tabular}

${ }^{*}$ All data are given as $\%$ of total fatty acid.

OMWW: olive mill waste water.

${ }^{a}$ Yilmaz et al., 2004 (the original data of the authors did not include any statistical deviations).

${ }^{\mathrm{b}}$ Sicuro et al., 2010 (no statistically significant differences have been observed).

${ }^{\mathrm{c}}$ Nasopoulou et al., 2011.

${ }^{\dagger}$ Indicates statistical significance within sea bream fed with FO (control) diet and 8\% OP diet $(p<0.05)$ according to the Wilcoxon test. 
OP has also been reported as a partial replacement of fish oil (FO) in gilthead sea bream (Sparus aurata) where it was found that feeding of OP to fish results in an improvement in its ability to prevent atherogenesis and therefore heart diseases (Nasopoulou et al., 2011). The growth performance factors of gilthead sea bream fed with FO diet in comparison with gilthead sea bream fed with OP exhibited no statistical differences regarding feed conversion ratios and specific growth rates. The levels of saturated (especially 16:0 and 18:0), monoenes (especially 18:1 cis), $\omega-3$ (20:5, EPA and 22:6, DHA) and $\omega-6$ (18:2) fatty acids of the fish fed with OP diet were found statistically decrease $(p<0.05)$ compared to the fish fed with FO diet. However this reduction in fatty acid content in gilthead sea bream fed with OP diet did not limit its biological activity. In fact, the biological activity against atheromatosis (expressed as Inhibitory Concentration for fifty percent inhibition, $\mathrm{IC}_{50}$, in $\mathrm{mg}$ of total lipids) of the sea bream fed with OP was found about 6 times higher than the corresponding activity of fish fed with FO diet ( 0.005 as opposed to 0.032 ) (Nasopoulou et al., 2011).

In practical terms, $\mathrm{IC}_{50}$ stands for the biological activity of the samples to inhibit by $50 \%$ the maximum reversible PAF-induced platelet aggregation, thus the lower the $\mathrm{IC}_{50}$ value of a food component observed, the more potent in cardioprotective terms (against atheromatosis and the prevention of CVDs) this food component is (Nasopoulou et al., 2011). It is worth mentioning that gilthead sea bream metabolized satisfactorily OP resulting in fish with statistically significant $(p<0.05)$ increased (more than six times) biological activity against atheromatosis and thus improved nutritional value. It is also worthy to note that gilthead sea bream fed with OP diet had a statistically decreased content $(\mathrm{p}<0.05)$ of EPA and DHA in comparison with the sea bream fed the FO diet. Thus, it could also be suggested that the cardio protective properties of the fish may not be directly linked to the fatty acid content but to the presence of lipid microconstituents originating from OP (Nasopoulou et al., 2011). This fact could possibly help aquaculturists, food scientists and nutritionists to re-assess the true benefits and the mechanism of action of $\omega-3$ fatty acids and clarify the existing literature discrepancies on the role of $\omega-3$ fatty acids (Begg et al., 2012).

The association of $\omega-3$ fatty acids and CVDs has also been revised recently by evaluating all randomized trials on the supplementation of omega-3 PUFAs to adults; in this review, the results of 20 studies on 68.680 patients were evaluated and $\omega-3$ fatty acids were not found to be statistically significantly associated with CVDs in various patient populations (Rizos, Ntzani, Bika, Kostapanos, \& Elisaf, 2012).

The implications of Nasopoulou et al. (2011) on OP are rather important: an alternative source of lipids (OP) can be used in aquaculture not only as a dietary lipid source but also as a source of compounds with antiatherogenic properties. These compounds can enrich the aquacultured fish (through fish feeds) and improve the nutritional value of both fish feeds and final commodity products (fish and fish products). A wide range of food with higher nutritional value could be produced using appropriate "health claims" according to EC 1924/2006.

\section{Agricultural Potential}

The main advantages of including agricultural by-products in the feeds and thus diets of animals is not only less dependency of livestock on highly expensive ingredients, such as grains, but also the reduction of costs related to waste management (Grasser et al., 1995). In 1985, FAO has published a review on the usage of olive by-products in ruminant feeding, especially sheep and cattle feeding, where the overall result was that olive cake (OC) can be used in animal feeding without risk for survival operations, but not for an intensive type of production (Sansoucy, 1985). It was also mentioned in that review that OC was a rough ligno-cellulose feed with high fibre and lignin contents and low crude protein contents; probably contained no toxic or inhibiting substances and induced acetic type of fermentation in the rumen, while OC's poor digestive and metabolic utilization was probably due mainly to its high degree of lignification and to the technological process for oil extraction in which it is frequently subjected to high heat (Sansoucy, 1985).

However over the last 2 decades new scientific research has focused on: optimizing olive by-products nutritive value; characterizing and quantifying phenolic compounds and fatty acids and evaluating their potential effects on the diet, on the animal performance and product quality. A more recent review updating data available on the aforementioned issues has been conducted by Molina-Alcaide and Yáñez-Ruiz (2008) presenting recent knowledge on the inclusion of by-products from olive trees and olive oil extraction in the diets offered to goats, lambs and ewes. The authors defined three main categories of olive by-products: 1) olive leaves, which actually refers to a mixture of leaves and branches, 2) OCs, which consist of olive pulp, skin, stone and water (similar to the above mentioned OP) and 3) other by-products, such as olive pulp and olive skins as individual compounds, evaluating them with respect to their composition, digestion, ruminal fermentation, and their impact on animal performance and product quality, with focus to their fatty acid profile (Molina-Alcaide \& Yáñez-Ruiz, 2008). 
$\mathrm{OC}$ inclusion in ruminant diets, promotes different responses in rumen fermentation, depending on the method of administration and the proportion in the diet, moreover provides cheap energy and fibre to the animal, while high-fat OC may be used to improve the quality of the fat in the animal products (Molina-Alcaide \& Yáñez-Ruiz, 2008).

More specific according to the reviewed data the use of olive by-products rich in oil (such as OC) in animal feed, increased the content of oleic acid (C18:1 $\omega-9)$ and the total mono-unsaturated fatty acid content in milk and reduced the content of saturated fatty acids, thus improving the lipid profile of milk. With regards to the quality of meat derived from animals partly fed on olive by-products, the overall acceptability of the meat as assessed by a taste panel, was slightly reduced compared with meat from animals receiving conventional concentrate foods, yet the impact on meat taste required further study (Molina-Alcaide \& Yáñez-Ruiz, 2008).

The effect of OP feed on productive performance and meat quality of growing rabbits has also been studied. The nutritional quality of rabbit meat could be improved by adding a 5\% concentration of OP to the standard diet. To achieve such goal, only OPs of high quality in terms of pro-oxidant/antioxidant content should be used. Specifically, OPs with a peroxide value less than $10 \mathrm{meq} / \mathrm{kg}$ and an ortho-diphenol concentration higher than 20 $\mathrm{g} / \mathrm{kg}$ can guarantee a satisfactory meat oxidative stability (Dal Bosco et al., 2012).

Moreover OP inclusion in rabbits' feeds resulted to enriching meat in monounsaturated FAs, such as oleic acid, which has recognized beneficial effects on human health, thus the authors recommended the use of OP in rabbit diet with caution, taking into account the quality of the by-product in terms of oxidative status (Dal Bosco et al., 2012).

Another recent study evaluated the effect of two by-products of the olive oil extraction industry - olive soapstocks and OP oil - as added fat sources into feed concentrates on the chemical composition and oxidative stability of Iberian pigmeat. The obtained results showed that the added fat source had no impact on the chemical composition, colour and fatty acid composition of the pig meat (gluten biceps muscle), however, the feeding system had a significant effect on protein $(p<0.05), \gamma$-tocopherol $(p<0.05)$, colour $(p<0.01)$ and fatty acid composition of pig meat (gluten biceps muscle) (González, Hernández-Matamoros, \& Tejeda, 2012).

In a study evaluating the effect of feeding agricultural by-products on the performance of lactating Awassi ewes, OC has been included at a level of $20 \%$ of the dry matter content of conventional diets of lactating Awassi ewes without any detrimental effects on animal performance (Shdaifat, Al-Barakah, Kanan, \& Obeidat, 2013). In detail, no significant differences have been found between OC and conventional treatment with respect to digestibility, initial body weight $(\mathrm{BW})$, final BW, BW change, milk production and milk composition, except for milk fat content which tended to be greater for the conventional treatment than for the OC treatment (Shdaifat et al., 2013).

In a similar study for lambs, the effects of different forms of OC (crude, alkali treated or ensiled OC) on growth performances and carcass quality of Awassi lambs have been studied and it was concluded that alkali treated or ensiled OC exhibited no differences compared to crude olive cake (COC) when fed to the growing Awassi lambs Adoption this option provides the fattening industry with an inexpensive nonconventional feed ingredient and reducing the environmental pollution caused by wastes disposal in the olive industry (Omar, Daya, \& Ghaleb, 2012). All the above mentioned studies are summarised in Tables 5 and 6. 
Table 5. Effect of feeding diets enriched with olive by-products on intake (g/day) and animal productivity - milk yield (g/day) and composition

\begin{tabular}{|c|c|c|c|c|c|c|c|c|}
\hline \multirow{2}{*}{$\begin{array}{l}\text { Olive } \\
\text { by-product }\end{array}$} & \multirow[t]{2}{*}{ Animal } & \multirow{2}{*}{$\begin{array}{l}\text { Average daily } \\
\text { feed gain }(\mathrm{g})\end{array}$} & \multirow{2}{*}{$\begin{array}{l}\text { Milk yield } \\
\text { (g/day) }\end{array}$} & \multicolumn{4}{|c|}{ Milk composition } & \multirow[t]{2}{*}{ Reference } \\
\hline & & & & $\mathrm{CP}$ & FAT & $\mathrm{U}: \mathrm{S}$ & MU & \\
\hline $\mathrm{CON}$ & ewe & - & 1157 & 4.0 & 7.4 & - & - & Shdaifat et al., 2013 \\
\hline $\mathrm{OC}$ & ewe & - & 1117 & 4.0 & 7.0 & - & - & \\
\hline $\mathrm{COC}$ & $\begin{array}{l}\text { Awassi } \\
\text { lamb }\end{array}$ & 335 & - & - & - & - & - & Omar et al., 2012 \\
\hline $\begin{array}{l}\text { Alkali treated } \\
\text { OC }\end{array}$ & $\begin{array}{l}\text { Awassi } \\
\text { lamb }\end{array}$ & 332 & - & - & - & - & - & \\
\hline Ensiled OC & $\begin{array}{l}\text { Awassi } \\
\text { lamb }\end{array}$ & 325 & - & - & - & - & - & \\
\hline Palleted OC & $\begin{array}{l}\text { Awassi } \\
\text { lamb }\end{array}$ & 227 & - & - & - & - & - & \\
\hline control & rabbit & 144 & - & - & - & - & - & Bosco et al, 2012 \\
\hline $\begin{array}{l}\text { OP (mixed } \\
\text { cultivar) }\end{array}$ & rabbit & 128 & - & - & - & - & - & \\
\hline OP (Frantoio) & rabbit & 126 & - & - & - & - & - & \\
\hline OP (Coratina) & rabbit & 135 & - & - & - & - & - & \\
\hline $\mathrm{COC}$ & goat & - & 1031 & 3.3 & 5.2 & 0.8 & 6.02 & $\begin{array}{l}\text { Molina-Alcaide et } \\
\text { al., } 2008\end{array}$ \\
\hline $\mathrm{COC}$ & ewe & - & 772 & 5.8 & 6.6 & 0.5 & 20.7 & \\
\hline $\mathrm{COC}$ & lamb & 191 & - & - & - & - & - & \\
\hline COC silage & goat & -31 & 2050 & 3.9 & 4.3 & & & \\
\hline COC silage & goat kids & 39 & - & - & - & - & & \\
\hline COC silage & ewe & 79 & 2120 & - & 5.4 & & & \\
\hline COC silage & lamb & $157-176$ & - & - & - & - & - & \\
\hline COC silage & cow & -312 & 1734 & 3.0 & 4.0 & & & \\
\hline EOC & lamb & $2-62$ & - & - & - & - & - & \\
\hline
\end{tabular}

CON: conventional diet; OC: olive cake; COC: crude olive cake; OP: olive pomace; EOC: extracted olive cake; CP: Crude protein (g/100g milk); Fat (g/100g milk); U:S: unsaturated/saturated fatty acids; MU: monounsaturated fatty acids $(\mathrm{g} / 100 \mathrm{~g})$ total fatty acids. 
Table 6. Chemical composition, colour and fatty acid profile of meat from rabbits and Iberian pigs fed with olive pomace $(\mathrm{OP})$ enriched diets

\begin{tabular}{|c|c|c|c|c|c|c|}
\hline Dietary treatment: & $\begin{array}{l}\text { Control }^{\mathrm{a}} \\
\text { Rabbit }\end{array}$ & $\mathrm{OP}^{1, \mathrm{a}}$ & $\mathrm{OP}^{2, \mathrm{a}}$ & $\mathrm{OP}^{3, \mathrm{a}}$ & $\begin{array}{l}\mathrm{OP}^{\mathrm{b}} \text { feeding system } 1 \\
\text { Iberian pig }\end{array}$ & $\mathrm{OP}^{\mathrm{b}}$ feeding system 2 \\
\hline \multicolumn{7}{|c|}{ Chemical composition $\quad(g / 100 g)$} \\
\hline Moisture & 75.0 & 75.1 & 75.0 & 75.2 & 70.0 & 69.0 \\
\hline $\mathrm{CP}$ & 21.4 & 20.9 & 20.9 & 20.6 & 23.2 & 24.1 \\
\hline Lipids & 2.19 & 2.64 & 2.72 & 2.59 & 5.28 & 5.41 \\
\hline Ash & 1.44 & 1.35 & 1.36 & 1.55 & 1.20 & 1.22 \\
\hline \multicolumn{7}{|l|}{ Color } \\
\hline $\mathrm{L}$ & 63.7 & 62.1 & 61.9 & 62.4 & 40.4 & 43.5 \\
\hline $\mathrm{a}$ & 6.90 & 5.18 & 5.18 & 5.12 & 7.42 & 9.49 \\
\hline $\mathrm{b}$ & 0.39 & 0.49 & 0.60 & 0.61 & 7.42 & 8.98 \\
\hline \multicolumn{7}{|c|}{ Fatty acids ( $\%$ of total fatty acids) } \\
\hline 14:0 & 2.58 & 3.15 & 2.73 & 2.31 & 1.37 & 1.38 \\
\hline 16:0 & 28.2 & 29.0 & 27.2 & 27.6 & 22.3 & 21.8 \\
\hline 18:0 & 8.16 & 6.54 & 7.38 & 5.03 & 11.1 & 10.5 \\
\hline Others & 2.15 & 2.57 & 2.30 & 2.15 & 0.32 & 0.25 \\
\hline Saturated & 41.0 & 41.3 & 39.7 & 37.1 & 35.1 & 33.9 \\
\hline $14: 1 \omega-6$ & 0.26 & 0.23 & 0.19 & 0.24 & - & - \\
\hline $16: 1 \omega-7$ & 3.52 & 2.98 & 2.45 & 2.41 & 1.93 & 2.02 \\
\hline $18: 1 \omega-9$ & 23.8 & 26.7 & 28.2 & 32.6 & 52.8 & 53.8 \\
\hline Others & 0.76 & 0.87 & 1.25 & 1.31 & 1.85 & 1.62 \\
\hline MUFA & 28.3 & 30.8 & 32.0 & 36.5 & 55.0 & 56.0 \\
\hline $18: 2 \omega-6$ & 20.1 & 17.6 & 18.6 & 16.8 & 7.80 & 8.15 \\
\hline $20: 3 \omega-6$ & 0.39 & 0.37 & 0.44 & 0.32 & - & - \\
\hline $20: 4 \omega-6$ & 3.81 & 4.12 & 3.91 & 3.51 & - & - \\
\hline $18: 3 \omega-3$ & 2.74 & 2.39 & 2.31 & 2.29 & 0.54 & 0.55 \\
\hline $20: 3 \omega-3$ & 0.11 & 0.05 & 0.09 & 0.06 & - & - \\
\hline $20: 5 \omega-3$ & 0.46 & 0.38 & 0.30 & 0.42 & - & - \\
\hline $21: 5 \omega-3$ & 0.25 & 0.34 & 0.37 & 0.39 & - & - \\
\hline $22: 5 \omega-3$ & 0.78 & 0.69 & 0.59 & 0.61 & - & - \\
\hline $22: 6 \omega-3$ & 0.53 & 0.48 & 0.36 & 0.57 & - & - \\
\hline Others & 1.42 & 1.60 & 1.27 & 1.38 & - & - \\
\hline PUFA & 30.6 & 28.0 & 28.3 & 26.4 & 8.34 & 8.71 \\
\hline$\omega-3 / \omega-6$ & 0.20 & 0.19 & 0.17 & 0.21 & 0.07 & 0.07 \\
\hline
\end{tabular}

$\mathrm{CP}$ : Crude protein; $\mathrm{OP}^{1}$ : mixed olive cultivars; $\mathrm{OP}^{2}$ : Frantoio olive cultivar; $\mathrm{OP}^{3}$ : Coratina olive cultivar.

Feeding system 1: Iberian pigs fed with an oleic-enriched concentrate; Feeding system 2: Iberian pigs fed with acorns, pasture and oleic-enriched concentrate.

a: Bosco et al., 2012.

b: González et al., 2012. 


\section{Conclusions}

In this review paper, the promising potential of olive by-products such as OP as a lipid source of nutrients has been highlighted by reviewing all the studies on the nutritional value of OP and its major constituents. Marine biotechnological applications of OP have been shown for the sustainable production of fish feeds. By doing so, the positive impact is multilevel: OP, instead of polluting the environment and constituting a major waste management problem, is used in the sustainable production of fish feed and thereafter aquacultured fish with higher nutritional value. Moreover olive by-products such as OC represent an important group of feed resources for ruminants in the Mediterranean areas. Several studies have been conducted in recent years, showing the potential use of this olive by-product in terms of both animal performance and product quality.

With this review paper, we wish to focus attention on the benefits of using OP in animal and fish feeds on three different levels: a) growing olive plants does not require high amounts of water (Cammalleri et al., 2010) and this fact is of crucial importance given the forecasted climate change in the Mediterranean region, b) OP and fish fed with OP have important nutritional properties against CVDs (Nasopoulou et al., 2011) and c) there is a clear environmental gain by valorizing an olive-oil industry by-product (Alburquerque et al., 2004).

In conclusion, the use of OP in agriculture and aquaculture delivers gains at three levels and these should be evaluated in terms of water-efficiency, improved nutritional value of the final animal and fish feeds and final food and also sustainable production of animal and fish feeds (with possible decreased dependency on grains and fish oil, respectively).

\section{Contributors}

Both authors read and approved the final manuscript. IZ contributed to the conception of this review paper and edited the manuscript and $\mathrm{CN}$ edited the manuscript.

\section{References}

Amro, B., Aburjai, T., \& Al-Khalil, S. (2002). Antioxidative and radical scavenging effects of olive cake extract. Fitoterapia, 73(6), 456-461. http://dx.doi.org/10.1016/S0367-326X(02)00173-9

Alburquerque, J. A., Gonzalvez, J., Garcia, D., \& Cegarra, J. (2004). Agrochemical characterisation of “alperujo", a solid by-product of the two-phase centrifugation method for olive oil extraction. Bioresources Technology, 91(2), 195-200. http://dx.doi.org/10.1016/S0960-8524(03)00177-9

Begg, A., Connolly, S., Halcox, J., Kaba, A., Main, L., Ray, K., ... Yellon, D. (2012). Omega-3 fatty acids in cardiovascular disease: re-assessing the evidence. British Journal of Cardiology, 19, 79-84. http://dx.doi.org/10.5837/bjc.2012.016

Borja, R., Martín, A., Rincón, B., \& Raposo, F. (2003). Kinetics for substrate utilization and methane production during the mesophilic anaerobic digestion of two phases olive pomace (TPOP). Journal of Agricultural and Food Chemistry, 51(11), 3390-3395. http://dx.doi.org/10.1021/jf021059n

Brunetti, G., Plaza, C., \& Senesi, N. (2005). Olive pomace amendment in Mediterranean conditions: effect on soil and humic acid properties and wheat (Triticum turgidum L.) yield. Journal of Agricultural and Food Chemistry, 53(17), 6730-6737. http://dx.doi.org/10.1021/jf050152j

Cammalleri, C., Agnese, C., Ciraolo, G., Minacapilli, M., Provenzano, G., \& Rallo, G. (2010). Actual evapotranspiration assessment by means of a coupled energy/hydrologic balance model: validation over an olive grove by means of scintillometry and measurements of soil water contents. Journal of Hydrology, 392(1-2), 70-82. http://dx.doi.org/10.1016/j.jhydrol.2010.07.046

Cardoso, S. M., Silva, A. M. S., \& Coimbra, M. A. (2002). Structural characterisation of the olive pomace pectic polysaccharide arabinan side chains. Carbohydrate Research, 337(10), 917-924. http://dx.doi.org/10.1016/S0008-6215(02)00082-4

Charles, H., Godfray, J., Beddington, J. R., Crute, I. R., Haddad, L., Lawrence, D., ... Toulmin, M. (2010). Food Security: The Challenge of Feeding 9 Billion People. Science, 327(5967), 812-818. $\mathrm{http}: / / \mathrm{dx}$.doi.org/10.1126/science.1185383

Dal Bosco, A., Mourvaki, E., Cardinali, R., Servili, M., Sebastiani, B., Ruggeri, S., ... Castellini, C. (2012). Effect of dietary supplementation with olive pomaces on the performance and meat quality of growing rabbits. Meat Science, 92(4), 783-788. http://dx.doi.org/10.1016/j.meatsci.2012.07.001 
De la Puerta, R., Marquez-Martin, A., Fernandez-Arche, A., \& Ruiz-Gutierrez, V. (2009). Influence of dietary fat on oxidative stress and inflammation in murine macrophages. Nutrition, 25(5), 548-554. http://dx.doi.org/10.1016/j.nut.2008.10.010

Demopoulos, C. A., Karantonis, H. C., \& Antonopoulou, S. (2003). Platelet activating factor - a molecular link between atherosclerosis theories. European Journal of Lipid Science and Technology, 105, 705-716. http://dx.doi.org/10.1002/ejlt.200300845

Di Giovacchino, L. (1996). Olive harvesting and olive oil extraction. In D. Boskou (Ed.), Olive Oil: Chemistry and Technology (pp. 12-51). Illinois: AOCS Press Champaign.

FAO Fisheries and Aquaculture Department. (2010). The State of World Fisheries and Aquaculture. Retrieved from http://www.fao.org/docrep/013/i1820e/i1820e.pdf

Fernández-Arche, A., Marquez-Martin, A., De la Puerta Vazquez, R., Perona, J. S., Terencio, C., Perez-Camino, C., \& Ruiz-Gutierrez, V. (2009). Long-chain fatty alcohols from pomace olive oil modulate the release of proinflammatory mediators. Journal of Nutritional Biochemistry, 20(3), 155-162. http://dx.doi.org/10.1016/j.jnutbio.2008.01.007

Grasser, L. A., Fadel, J. G., Garnett, I., \& Depeters, E. (1995). Quantity and economic importance of 9 selected byproducts used in California dairy rations. Journal of Dairy Science, 78(4), 962-971. http://dx.doi.org/10.3168/jds.S0022-0302(95)76711-X

González, E., Hernández-Matamoros, A., \& Tejeda, J. F. (2012). Two by-products of the olive oil extraction industry as oleic acid supplement source for Iberian pigs: effect on the meat's chemical composition and induced lipoperoxidation. Journal of the Science of Food and Agriculture, 92(12), 2543-2551. http://dx.doi.org/10.1002/jsfa.5669.

Jackson, A. J. (2007). Challenges and opportunities for the fishmeal and fish oil industry. Feed Technology Update, 2(1), 9 .

Karantonis, H. C., Tsantila, N., Stamatakis, G., Samiotaki, M., Panayotou, G., Antonopoulou, S., \& Demopoulos, C. A. (2008). Bioactive polar lipids in olive oil, pomace and waste byproducts. Journal of Food Biochemistry, 32(4), 443-459. http://dx.doi.org/10.1111/j.1745-4514.2008.00160.x/abstract

Martín García, A. I., Moumen, A., Yáñez Ruiz, D. R., \& Molina-Alcaide, E. (2003). Chemical composition and nutrients availability for goats and sheep of two-stage olive cake and olive leaves. Animal Feed Science and Technology, 107(1-4), 61-74. http://dx.doi.org/10.1016/S0377-8401(03)00066-X

Molina-Alcaide, E., \& Yáñez-Ruiz, D. R. (2008). Potential use of olive by-products in ruminant feeding: A review. Animal Feed Science $\quad$ and $247-264$. http://dx.doi.org/10.1016/j.anifeedsci.2007.09.021

Muik, B., Lendl, B., Molina-Díaz, A., Pérez-Villarejo, L., \& Ayora-Cañada, M. J. (2004). Determination of oil and water content in olive pomace using near infrared and Raman spectrometry. A comparative study. Analytical and Bioanalytical Chemistry, 379(1), 35-41. http://dx.doi.org/10.1007/s00216-004-2493-5

Nasopoulou, C., Stamatakis, G., Demopoulos, C. A., \& Zabetakis, I. (2011). Effects of olive pomace and olive pomace oil on growth performance, fatty acid composition and cardio protective properties of gilthead sea bream (Sparus aurata) and sea bass (Dicentrarchus labrax). Food Chemistry, 129(3), 1108-1113. http://dx.doi.org/10.1016/j.foodchem.2011.05.086

Nasopoulou, C., \& Zabetakis, I. (2012). Benefits of fish oil replacement by plant originated oils in compounded fish feeds. A review. LWT-Food Science and Technology, 47(2), $217-224$. http://dx.doi.org/10.1016/j.lwt.2012.01.018

Naylor, R. L., Goldburg, R. J., Primavera, J. H., Kautsky, N., Beveridge, M. C. M., Clay, J., ... Troell, M. (2000). Effect of aquaculture on world fish supplies. Nature, 405(6790), 1017-1024. http://dx.doi.org/10.1038/35016500

Official Journal of European Communities. (1992). Regulation EEC No 356/92. Retrieved from http:/eur-lex.europa.eu/LexUriServ/LexUriServ.do?uri=CONSLEG:1992R0356:19921101:EN:PDF

Omar, J. M. A., Daya, R., \& Ghaleb, A. (2012). Effects of different forms of olive cake on the performance and carcass quality of Awassi lambs. Animal Feed Science and Technology, 171(2-4), 167-172. http://dx.doi.org/10.1016/j.anifeedsci.2011.11.002 
Palmieri, D., Aliakbarian, B., Casazza, A. A., Ferrari, N., Spinella, G., Pane, B., ... Palombo, D. (2012). Effects of polyphenol extract from olive pomace on anoxia-induved endothelial dysfunction. Microvascular Research, 83(3), 281-289. http://dx.doi.org/10.1016/j.mvr.2012.02.010

Pike, I. H., \& Jackson, A. (2010). Fish oil: production and use now and in the future. Lipid Technology, 22(3), 59-61. http://dx.doi.org/10.1002/lite.201000003

Rizos, E. C., Ntzani, E. E., Bika, E., Kostapanos, M. S., \& Elisaf, M. S. (2012). Association between omega-3 fatty acid supplementation and risk of major cardiovascular disease events. A systematic review and meta-analysis. The Journal of the Americam Medical Association, 308(10), 1024-1033. http://dx.doi.org/10.1001/2012.jama.11374

Rodriguez-Rodriguez, R., Herrera, M. D., Alvarez de Sotomayor, M., \& Ruiz-Gutierrez, V. (2009). Effects of pomace olive oil-enriched diets on endothelial function of small mesenteric arteries from spontaneously hypertensive rats. British Journal of Nutrition, 102(10), 1435-1444. http://dx.doi.org/10.1017/S0007114509990754

Roig, A., Cayuela, M. L., \& Sánchez-Monedero, M. A. (2006). An overview on olive mill wastes and their valorisation methods. Waste Management, 26(9), 960-969. http://dx.doi.org/10.1016/j.wasman.2005.07.024

Sansoucy, R. (1985). Olive by-products for animal feed. FAO Anim. Production Health, 43, FAO, Rome. Retrieved from http:/www.fao.org/docrep/003/X6545E/X6545E00.HTM

Saviozzi, A., Levi-Minzi, R., Cardelli, R., Biasci, A., \& Riffaldi, R. (2001). Suitability of moist olive pomace as soil amendment. Water Air Soil Pollution, 128(1-2), 13-22. http://dx.doi.org/10.1023/A:1010361807181

Servili, M., Esposto, S., Veneziani, G., Urbani, S., Taticchi, A., Di Maio, I., ... Monterodo, G. (2011). Improvement of bioactive phenol content in virgin olive oil with an olive-vegetation water concentrate produced by membrane treatment. Food Chemistry, 124(4), 1308-1315. http://dx.doi.org/10.1016/j.foodchem.2010.07.042

Shdaifat, M. M., Al-Barakah, F. S., Kanan, A. Q., \& Obeidat, B. S. (2013). The effect of feeding agricultural by-products on performance of lactating Awassi ewes. Small Ruminant Research. http://dx.doi.org/10.1016/j.smallrumres.2013.01.014

Sicuro, B., Barbera, S., Dapra, F., Gai, F., Gasco, L., Paglialonga, G., ... Vilella, S. (2010). The olive oil by-product in "rainbow trout Onchorynchus mykyss (Walbaum)" farming: productive results and quality of the product. Aquaculture Research, 41(10), 475-486. http://dx.doi.org/10.1111/j.1365-2109.2010.02514.x

Tsantila, N., Karantonis, H. C., Perrea, D. N., Theocharis, S. E., Iliopoulos, D. G., Antonopoulou, S., \& Demopoulos, C. A. (2007). Antithrombotic and antiatherosclerotic properties of olive oil and olive pomace polar extracts in rabbits. Mediators of Inflammation, 2007(36204), 1-11. http://dx.doi.org/10.1155/2007/36204

Tsantila, N., Karantonis, H. C., Perrea, D. N., Theocharis, S. E., Iliopoulos, D. G., Iatrou, C., ... Demopoulos, C. A. (2010). Atherosclerosis regression in rabbits upon olive pomace polar lipid extract administration. Nutrition, Metabolism and Cardiovascular Diseases, 20(10), 740-747. http://dx.doi.org/0.1016/j.numecd.2009.06.008

Yilmaz, E., Naz, M., \& Akyurt, I. (2004). Effect of dietary olive pomace oil and L-carnitine on growth and chemical composition of african catfish, Clarias Gariepinus (Burchell, 1822). Israeli Journal of Aquaculture, 56(1), 14-21. Retrieved from http:/www.google.gr/url?sa=t\&rct=j\&q=\&esrc=s\&source=web\&cd=3\&ved=0CEYQFjAC\&url=http $\% 3 \mathrm{~A}$ \%2F\%2Fwww.mku.edu.tr\%2Fgetblogfile.php\%3Fkeyid\%3D71\&ei=jvlwUZH7CoLVswbzk4HYDg\&usg= AFQjCNEUSBs19V9_29dsxpU5rBAHVfk_Aw\&bvm=bv.45373924,d.Yms

\section{Copyrights}

Copyright for this article is retained by the author(s), with first publication rights granted to the journal.

This is an open-access article distributed under the terms and conditions of the Creative Commons Attribution license (http://creativecommons.org/licenses/by/3.0/). 